\title{
Okul Öncesi Eğitimde Cinsiyet Eşitliği Üzerine Betimsel Bir Çalışma
}

\section{Zeynep TEMIZ*, Firdevs Melis CíN**}

Öz: Bütün sosyal gelişmelere ve kadın hareketlerine rağmen bütün dünyada halen insanları cinsiyetlerine göre ayıran ayrımcı kültürel değerler bulunmaktadır. Okul öncesi eğitim ortamı cinsiyet eşitliği üzerine farkındalık yaratılabilecek ayrıcalıklı bir ortam olmasına karşın son zamanlara kadar eğitim programlarında cinsiyet eşitliği pek vurgulanmamıştır $\mathrm{Bu}$ nedenle eğitsel değerler açısından doğal ortamda gerçekleşen cinsiyet eşitliği ile ilgili gerçek uygulamaların ne olduğu hakkında bilgi edinmek önem taşımaktadır. Bu çalışma 'Cinsiyet Eşitliği Ölçeği’ni Türkçe' ye çevirip geçerliliğini ve güvenirliliğini incelemeyi hedeflemektedir. Ölçeğin kurumsal, eğitim-öğretim, ve kişisel olmak üzere üç alt alanı bulunmakta ve toplamda 30 madde içermektedir. Bu 30 likert-tipi soruya ek olarak iki adet de açık uçlu soru içeren ölçek, dört uzmanın yardımı ile Türkçe' ye çevrilmiştir. Türkçe' ye uyarlanan ölçek 46 erkek ve 92 kadın okul öncesi öğretmenine uygulanmıştır. İç geçerliliği ölçmek için Cronbach Alpha katsayısı kurumsal, eğitim-öğretim, kişisel alt alanlarına ve ölçeğin tamamı için hesaplanmış, sırasıyla. 77, .86, .76, .78 bulunmuştur. Sonuç olarak Cinsiyet Eşitliği Ölçeğinin Türkçe versiyonu okul öncesi eğitimde cinsiyet eşitliğini ölçmek için yeterli bulunmuştur. Ölçeğin Türkçe' ye uyarlanmasının ardından ölçek 152 farklı öğretmene tekrar uygulanmıştır. İkinci uygulamaya 97 kadın ve 55 erkek öğretmen katılmıştır. Kadın ve erkek öğretmenlerin cinsiyet eşitliği puanları MANOVA testi yapılarak karşılaştırılmıştır. İstatistiksel olarak iki grup arasında anlamlı bir fark bulunamamıştır ve öğretmenlerin açık uçlu sorulara verdikleri yanıtlar içerik analizi yapılarak değerlendirildikten sonra da aynı sonuca ulaşılmıştır. Çalışmanın sonuçlarına göre, her iki cinsiyetteki öğretmenler de sınıflarında cinsiyetçi kalıpları, yargıları ve önyargıları yıkmak için çaba göstermektedir.

Anahtar kavramlar: Cinsiyet eşitliği, okul öncesi eğitim, ölçek adaptasyonu

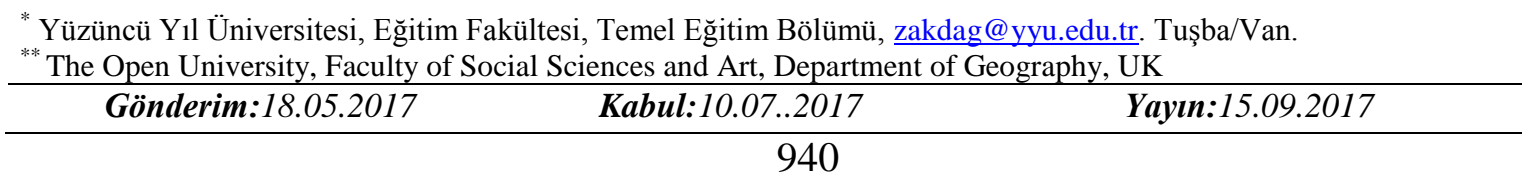




\section{A Descriptive Study on Gender Equity in Pre-school Education}

Abstract: There are still gender-based discriminatory cultural values despite increasing women movements across the world. Although pre-school education is a privileged setting to create an awareness of gender equity, it has not been emphasized in teaching program until recently in Turkey. Therefore, within the context of concerning educational values, it is essential to explore real educational practices at schools. This study aims to present the validity and adaptation of the Gender Equity Scale (Vendrell, 2014) into Turkish. It consists of three subscales, namely institutional, didactic and personal field. In total it includes 30 items and Likert-type scale (5 point) questions; the Gender Equity Scale has two open ended questions. With the help of the four experts the scale was translated into Turkish. The Turkish version of the scale was administered to 46 males and 92 female pre-school education teachers. For the scale's internal consistency, Cronbach's Alpha coefficients were calculated for the Institutional subscale, didactic subscale, personal subscale and the scale total, and it was found that they are respectively $.77, .86, .76, .78$. As a consequence, the properties of the Turkish version of the Gender Equity scale were satisfactory, and can be used to assess gender equality in pre-school education in Turkey. After adapting the Gender Equity Scale in Turkish, it was administered to 97 females and 55 male teachers again. When a MANOVA test was conducted to compare the gender equity scores for males and females teachers, there was no significant difference between two genders. Teachers' open ended questions were analyzed by content analysis method. Results confirm that both female and male teachers are trying to overcome gender stereotypes and prejudices in their classes.

Keywords: Gender equity, pre-school education, scale adaptation 
Toplumsal cinsiyet rolleri kadın ve erkeğin biyolojik farklılıklarına bağlı olmaksızın kültürel, sosyal, ekonomik ve tarihi nedenlere dayanarak kadın ve erkeklere yüklenen rolleri ve sorumlulukları ifade eder. Cinsiyetimiz biyolojik olarak belirlenir; fakat toplumsal cinsiyet rolleri toplum tarafından bize öğretilir. Toplumsal cinsiyet rollerini çok küçük yaştan itibaren öğreniriz. Daha bebekken kız çocuklar için pembe, erkek çocuklar için mavi rengin seçilmesi ilerde kadın ve erkeklerin yeterlilikleri konusunda doğal olmayan ayrımlar yaratır (Üner, 2008). Görsel medyada erkek çocukların top oynarken, kız çocukların ise pembeler içinde bebekleriyle oynarken gösterilmesi bu doğal olmayan ayrımı destekleyen ve pekiştiren bir etki yaratmaktadır (Gündüz-Kalan, 2010). Erkeklerin ailenin geçimini sağlamaktan sorumlu olup, kadınların ev işleri ve çocuk bakımından sorumlu görülmeleri gibi taraflı toplumsal cinsiyet rolleri kadınların siyasetten iş gücüne katılımına her türlü kamusal alanda erkeklere oranla daha az temsil edilmelerine neden olmaktadır. Bu adaletsiz durumun önlenmesi için toplumsal cinsiyet eşitliği kavramı yasalar yoluyla sağlanmaya çalışılmaktadır. Toplumsal cinsiyet eşitliği kadın ve erkek bireylerin hem aile hem de toplum içinde kaynaklardan, fırsatlardan ve hizmetlerden eşit şekilde yararlanmasını öngörmektedir (World Health Organization, 1998). Eğitim kadınlar açısından sadece bir insan hakkı olarak değil güçlü bir araç olarak ele alınmalıdır. Eğitim kadınların gücünü arttırmak için stratejik önem taşıyan bir yatırımdır. İyi eğitim alan kadınlar daha sağlıklı olurlar, iş gücüne daha çok katılır doğal olarak da daha çok kazanırlar. Daha az çocuğa sahip oldukları gibi sahip oldukları çocuklara daha iyi eğitim ve sağlık imkânları sunarlar. Kız çocukları, iyi bir eğitim almaları ve kendilerine ekonomik olanaklar sunulması durumunda küçük yaşta evlenip çocuk doğurmaktan ziyade, bu olanakları kullanmayı seçerler. Ne yazık ki dünyanın dört bir yanında kız çocuklarını eğitime devam etmekten alıkoyan pek çok kültürel, ekonomik, sosyal ve dini engel bulunmaktadır (McCleary-Sills, Hanmer, Parsons \& Klugman, 2015). Gelişmekte olan ülkelerin hepsinde 
olduğu gibi Türkiye'de de eğitim-öğretim kademesi yükseldikçe, kız öğrencilerin eğitim alma imkânlarının azaldığı gözlenmektedir. Kız çocuklarının aleyhine gelişen bu durum onların eğitim hakkını elinden almakta ve eğitimde fırsat eşitliğinin sağlanmasını engellemektedir (Sarıer, 2010). Türk eğitim sistemindeki cinsiyete dayalı eşitsizlik sorunu, eğitimin tüm kademelerinde varlığını sürdürmektedir. Kültüre bağlı olarak eğitim eşitsizlikleri içinde en yaygın ve belirgini olarak karşımıza çıkan kız çocuklarının eğitimden yararlanamaması sonuçları düşünüldügünnde en tehlikeli eşitsizlik türüdür. Kız ve erkek çocuklarının okullaşma oranlarındaki cinsiyete dayalı eşitsizlik, onların eğitim imkân ve fırsatlarından yararlanma adaletsizliğini ortaya koymaktadır (Maya, 2013). Oysa ülkemizde T.C. Anayasası ile "Kimse eğitim-öğretim hakkından yoksun bırakılamaz." hükmü ve 1739 sayılı Milli Eğitim Temel Kanunu ile "genellik ve eşitlik” ve “fırsat ve imkân eşitliği” ilkeleri kabul edilmiştir. Her ne kadar yasalar kadın ve erkek eşitliğini sağlamak amacıyla oluşturulsalar da toplumda bu eşitliğin sağlanmasına engel olan başka faktörler bulunmaktadır. Yasal olarak sağlanan toplumsal cinsiyet eşitliğinin hayata geçirilmesine engel olan en önemli faktör toplumdaki bireylerin zihinlerinde yer eden kalıp yargılardır (gender streotypes). Kalıp yargılar bireylerin olay, durum ve nesneler hakkında zihinlerinde oluşturdukları imgelerdir. Kalıp yargılar zaman içinde önyargıların oluşmasında rol oynarlar. İnsanlar cinsiyet, ırk, meslek, azınlık gruplarına karşı kalıp yargılar oluşturmaya daha meyillidirler. Kalıp yargılar çocukken ailede başlar daha sonra okul ve toplum içinde zamanla pekişir ve içselleştirilir (Kalaycı, 2015).

Bandura'nın sosyal öğrenme kuramı insanların, neredeyse bütün davranış biçimlerini gözlem, model alma ve taklit yoluyla öğrendiklerini savunmaktadır (Bandura,1989). Çocuk gözlem yoluyla öğrenirken bir yandan da sürekli kendisine rol modeller aramaktadır (Kalayc1, 2015). Çocuklar çevrelerinde bulunan aile bireyleri, öğretmen, akraba ve arkadaşlarının davranış biçimlerini gözlemleyerek öğrenir ya da öğrendiği davranışı pekiştirir. Çocukların 
etkileşimde bulunduğu bir diğer model ise medya vasıtasıyla tanıştıkları çizgi film kahramanlarıdır. Medyada yer alan bu kahramanların davranışları da çocuklar tarafından model alınabilmektedir. Bu kahramanlar insan davranışlarına ve değerlerine dair pek çok konuda fikir vermektedir (Alan, 2009; Aral, Ceylan \& Bıçakçı, 2011; Asan, 2010; Ayranc1, Köşgeroğlu \& Günay, 2004; Günaydın, 2011; Gündüz-Kalan, 2010; Kalayc1, 2015; Oruç, Tecim \& Özyürek, 2011 ).

Ülkemizde eğitici amaçlı hazırlanan Pepe çizgi filmi incelendiğinde cinsiyetçi kalıp yargıların oluşmasına hizmet edecek pek çok durum tespit edilmiştir. Kadın erkek karakterler toplum tarafından kadın ve erkelere atfedilen rol, davranış ve giysi rengi gibi cinsiyetçi kalıp yargılar içinde sınırlandırılmıştır. Hem kadınlar, hem erkekler tarafından yapılabilecek olan çiçek sulama, sofra hazırlama, bebekle ilgilenme gibi işler, kadın karakterler tarafından yerine getirilirken; otomobil, bisiklet ve balon kullanma gibi beceriler ise erkek karakterlere tarafından yerine getirilmiştir. Pepe çizgi filminde karakterlerin duygusal durumlarından, oynadıkları oyunlara kadar, toplumsal cinsiyet eşitsizliği oluşturabilecek birçok mesaj verilmektedir (Kalaycı, 2015). Medya kadın ve erkeğin, kız ve erkek çocuğun konumlandırılışı ve davranış biçimleri konusunda model oluşturmaktadır. Kadının hep ev işleri ve çocukların bakımıyla ilgilenen kişi, erkeğin ise çalışan kişi rolleriyle gösterilmesi gözlemlediği diğer verilerle birlikte, çocukta cinsiyet rolleriyle ilgili kalıp yargıların pekişmesine katkı sağlamaktadır. Bu nedenle reklamlarda kız ve erkek çocukların kalıp yargılardan uzak ve sadece çocuk olma özelliklerine yönelik konumlandırılmaları kalıp yargıların kırılması ya da en azından pekiştirilmemesi açısından önem taşımaktadır (GündüzKalan, 2010).

Benzer şekilde ilköğretim ders kitapları incelendiğinde cinsiyetçi kalıp yargıların oluşmasına ve pekişmesine hizmet ettiği görülmektedir. İlköğretim ders kitaplarında daha çok çocuk bakımı ve ev işleri yaparken resmedilen karakterler kadınlardır. Bu kitaplarda, erkekler 
ise kamusal alanlarda kadınlara göre çok fazla resmedilmekte olduğundan, bu durum kamusal alanların erkelere ait olduğu kalıp yargısını güçlendirmektedir. Ayrıca, kadınların mesleki çeşitliliği öğretmenlik ve hemşirelikle sınırlı kalmaktadır (Esen \& Bağlı, 2002). Cinsiyet eşitliği kavramı üzerine yapılan araştırmalar, küçük çocukların eğitiminin hem kadın hem de erkek öğretmenler tarafından verilmesinin önemini vurgulamaktadır. Kadın ve erkek öğretmenlerin birlikte çalıştığı okullarda eğitim alan çocukların kadın ve erkeklere atfedilen cinsiyetçi kalıp yargıları geliştirmediği bulunmuştur (Vendrell, Capdevila, Dalmau, Geis, \& Ciller, 2014). Bu nedenle okul öncesi eğitim kurumları bahsedilen kalıp yargıların oluşmasının önlenmesinde ya da ortadan kaldırılmasında kilit rol oynamaktadır.

Okul öncesi eğitimde edinilen tutum ve davranışların etkililiği ve kalıcılığı göz önüne alındığında (Morrison, 2006), öğretmenlerin cinsiyet eşitliği ile ilgili uygulamaları, inançları ve tutumları önem kazanmaktadır. Bunlara dayanarak bu çalışmanın amacı okul öncesi eğitim öğretmenlerinin cinsiyet eşitliğine ile ilgili uygulamalarını incelemektir. Öğretmenlerin cinsiyet eşitliği uygulamalarını ölçmek için Vendrell ve diğerlerinin (2014) geliştirdiği ölçek kullanılmıştır. Çalışmanın sonunda elde edilen bulgular, Türkiye'de çok yoğun şekilde hissedilen cinsiyet eşitsizliği ile ilgili küçük yaşlardan itibaren alınabilecek önlemler konusunda fikir verebilir. Araştırma kapsamında aşağıdaki sorular incelenmiştir:

1. Vendrell ve diğerlerinin (2014) geliştirdiği Cinsiyet Eşitliği Ölçeğini Türkçe’ ye uyarlandığında geçerliliği ve güvenirliği sağlanabilir mi?

2. Okul öncesi eğitim öğretmenlerinin cinsiyet eşitliğine yönelik tutum puanları cinsiyete göre farklılık göstermekte midir?

3. Okul öncesi eğitim öğretmenlerinin cinsiyet eşitliği ile ilgili karşılaştıkları durumlar ve bunları önleme yolları nelerdir?

\section{Yöntem}


$\mathrm{Bu}$ çalışmada veri toplama aracı olarak Vendrell ve diğerlerinin (2014) okul öncesi eğitim kurumlarında cinsiyet eşitliğinin uygulanmasını ölçmek için geliştirdikleri ölçek kullanılmıştır. Cinsiyet Eşitliği Ölçeği’nin Türkçe’ye uyarlama çalışmasına ilk olarak ölçeği geliştirenlerden Roser Vendrell ile iletişim kurularak, ölçeğin Türkçe uyarlama çalışması için izin alınmıştır.

Ardından ölçeğin maddeleri Türkçe' ye çevrilmeye başlanmıştır. Araştırmacılardan birinin uzmanlık alanı okul öncesi eğitim diğerinin uzmanlık alanı cinsiyet eşitliği olduğundan ve iki araştırmacının da İngilizce yeterlilik düzeyi ileri seviyede olduğundan ölçek araştırmacılar tarafından bağımsız olarak Türkçe' ye çevrilmiştir. Ardından iki çeviri karşılaştırılarak arasındaki ufak farklılıklar giderilmiş ve \%100 uyumlu hale getirilmiştir. Türkçe’ ye çevrilen ölçek yine hem okul öncesi eğitim hem de cinsiyet eşitliği alanında yeterliliği olan iki farklı akademisyen tarafından incelenmiş, önerilen küçük değişiklikler yapılmıştır. Çeviri işlemi tamamlandıktan sonra, 10 yıl öğretmenlik ve 3 yıl idarecilik deneyimi bulunan bir okul öncesi öğretmeninden ölçek sorularını cevaplaması istenmiştir. İlk maddede yer alan resmi evrakların parantez içinde gelişim gözlem formları şeklinde açıklanması önerisiyle birlikte ölçeğe son hali verilmiştir. Cinsiyet eşitliği ölçeğinde toplamda 5'li Likert-Tip 30 madde bulunmaktadır. $\mathrm{Bu}$ maddeler "kesinlikle katılmıyorum"(1), “katılmıyorum”(2), “kararsızım”(3), “katılıyorum”(4), “kesinlikle katılıyorum”(5) şeklinde puanlanmaktadir.

Ölçek kurumsal analiz, eğitim-öğretim analizi, kişisel analiz olmak üzere 3 alt kategoriden oluşmaktadır. Kurumsal analiz okuldaki resmi evrakları, okul yönetimi ve okuldaki diğer çalışanları değerlendirmektedir. Bu alt kategorideki sorular okul personelinin iki cinsiyet için de okul ve okul dışındaki etkinliklerdeki katılımı, cinsiyet eşitliği değerlerinin okuldaki resmi evraklarda, pedagojik yaklaşımlarda, toplantılarda ele alınıp alınmadığı ile ilgilidir. Ayrıca okulda cinsiyet eşitliğini bu açılardan sağlamak için okulda aileler ve 
çocuklara eğitim verilip verilmediği üzerine yoğunlaşmaktadır. Eğitim-öğretim analizi eğitimsel etkinlikler, program ve materyalleri kapsamaktadır. $\mathrm{Bu}$ alandaki sorular eğitim programında ve serbest zaman etkinliklerinde sınıf içi işlerin dağılımı, akademik materyallerde ve kullanılan dilde cinsiyet eşitliği konularını içermektedir. Kişisel analiz alanı öğretmenlerin eğitimsel faaliyetler içinde cinsiyetçi kalıp yargıları ve cinsiyet ayrımcılığı hakkındaki inanışları ile ilgili bilgi toplamayı hedeflemektedir. Sorular çocukların cinsiyetlerinin oyunlarını, sınıfta çalışma şekillerini, sınıf disiplinini nasıl etkilediğini öğretmenlerin kişisel olarak algılamaları ile ilgilidir. Ayrıca ailelerin erkek öğretmenlere ve yöneticilere karşı düşünceleri de sorular arasında yer almaktadır. Buna ek olarak ölçek iki adet açık uçlu soru içermektedir. İlk açık uçlu soruda öğretmenlerin tanık olduğu cinsiyet eşitliği ile ilgili herhangi olumlu bir durumu açıklamaları istenmektedir. Benzer şekilde ikinci açık uçlu soru cinsiyetçi kalıp yargılar ve cinsiyet eşitliğine yönelik önyargılara dair yaşanan olumsuz bir durumun açıklanması ile ilgilidir.

Ölçeği uygulamadan önce Milli Eğitim Müdürlüğü’nden resmi izinler alınmıştır. Ölçek orijinal olarak 3-6 yaş arasındaki çocuklara eğitim veren öğretmenlere uygulanmak için geliştirildiğinden, Türkiye'de Van ve Siirt ilinde bulunan 3-6 yaş arasındaki çocuklara eğitim veren 138 öğretmene uygulanmıştır. Çalışmaya katılan öğretmenlerden 92'si kadın 46’s1 erkektir ve yaşları 22 ile 43 arasındadır, yaş ortalamaları 27,9 olup oldukça genç bir grubu temsil etmektedirler. Bu durum doğu illerinde öğretmen açığı daha fazla olduğu için her sene Van ve Siirt illerine yeni öğretmenlerin daha çok atanması ve çalışmaya katılan öğretmenlerin çoğunluğunun Milli Eğitim Bakanlığı'na bağlı okullarda çalışması ile açıklanabilir. Öğretmenlerin çalışma yılları da 1 ile 20 yıl arasında değişmekte ve ortalama çalışma yılı 4,3 olduğu için öğretmenlerin yaşları ile paralellik göstermektedir. Öğretmenlerin 76'sı bağımsız anaokulunda, 40’1 ilköğretime bağlı ana sınıflarında ve 20'si özel anaokullarında çalışmaktadır. Bağımsız anaokulları diğer okulların aksine sadece okul öncesi eğitim hizmeti 
sunmaktadır ve ortalama 5-6 sınıfa sahip olmakla birlikte 14 tane sınıfa sahip bağımsız anaokullarına da rastlanmaktadır. Van ili merkezinde 25 tane bağımsız anaokulu olduğu göz önüne alınınca çalışmaya katılan öğretmenlerin çoğunluğunun bağımsız anaokulunda çalışmasının nedeni anlaşılmaktadır. Çalışmaya katılan bütün öğretmenlere çalıştıkları okullarda ulaşılmıştır. Ölçeğin çevrilmesi aşamasında açık uçlu sorular sadece soruların anlaşılıp anlaşılmadığını görmek için sorulmuştur. Açık uçlu soruları çalışmaya katılan 138 öğretmenden 49’u cevaplandırmıştır. Verdikleri cevaplar soruların anlaşıldığını göstermektedir.

\section{Bulgular}

Ölçeğin Adaptasyonu: Ölçeğin yapı geçerliğini sağlamak ve öncelikle Türkçe uyarlamasında yer alan maddelerin ayırt edicilik düzeylerine bakmak için madde analizi ile her maddenin kendi faktörü için düzeltilmiş madde-toplam pearson çarpım moment korelasyon değerleri hesaplanmıştır. Tablo 1'de görüldügüü üzere korelasyon değerleri. 36 ile. 80 arasındadır.

Tablo 1. Pearson Çarpım Moment Korelasyon Analizi Sonuçları

\begin{tabular}{|l|l|l|}
\hline Alt Boyutlar & Maddeler & $\begin{array}{l}\text { Düzeltilmiş Madde } \\
\text { Toplam r }\end{array}$ \\
\hline \multirow{5}{*}{ Kurumsal } & Madde 1 & .49 \\
\cline { 2 - 3 } & Madde 2 & .56 \\
\cline { 2 - 3 } & Madde 3 & .38 \\
\cline { 2 - 3 } & Madde 4 & .72 \\
\hline & Madde 5 & .59 \\
\hline & Madde 6 & .70 \\
\hline & Madde 7 & .72 \\
\hline & Madde 8 & .54 \\
\hline & Madde 9 & .67 \\
\hline Ĕgitim-Öğretim & Madde 10 & .62 \\
\hline & Madde 11 & .72 \\
\hline & Madde 12 & .80 \\
\hline
\end{tabular}




\begin{tabular}{|c|c|c|}
\hline & Madde 13 & .76 \\
\hline & Madde 14 & .79 \\
\hline & Madde 15 & .70 \\
\hline & Madde 16 & .67 \\
\hline & Madde 17 & .66 \\
\hline Kişisel & Madde 18 & .60 \\
\hline & Madde 19 & .59 \\
\hline & Madde 20 & .60 \\
\hline & Madde 21 & .74 \\
\hline & Madde 22 & .69 \\
\hline & Madde 23 & .60 \\
\hline & Madde 24 & .54 \\
\hline & Madde 25 & .45 \\
\hline & Madde 26 & .36 \\
\hline & Madde 27 & .62 \\
\hline & Madde 28 & .45 \\
\hline & Madde 29 & .44 \\
\hline & Madde 30 & .39 \\
\hline
\end{tabular}

Madde analizine tekrar bakmak için ölçekten elde edilen ham puanlar küçükten büyüğe doğru sıralanmıştır. Bu sıralamaya göre alt \%27'lik grup ile üst \%27'lik grupların puanları bağımsız t-testi ile karşılaştırılmış ve sonuçlar Tablo 2'de verilmiştir. Bağımsız t testi sonuçlarına göre üst \%27'lik grupta yer alanların puanları ile alt \%27'lik grupta yer alanların puanları arasında istatistiksel olarak anlamlı bir fark bulunmuştur.

Tablo 2. Bağımsız t-testi sonuçları

\begin{tabular}{|c|c|c|c|c|c|c|c|c|c|}
\hline Maddeler & & Ort & SS & $\mathbf{t}$ & Maddeler & & Ort & SS & $\mathbf{t}$ \\
\hline \multirow{2}{*}{ Madde 1} & Alt \%27 & 2.22 & .89 & \multirow{2}{*}{-13.41} & \multirow{2}{*}{ Madde 16} & Alt $\% 27$ & 2.94 & 1.01 & \multirow{2}{*}{-12.18} \\
\hline & Üst $\% 27$ & 4.52 & .50 & & & Üst $\% 27$ & 5.00 & .00 & \\
\hline \multirow{2}{*}{ Madde 2} & Alt \%27 & 3.25 & 1.05 & \multirow{2}{*}{-9.97} & \multirow{2}{*}{ Madde 17} & Alt \%27 & 3.02 & .97 & \multirow{2}{*}{-12.19} \\
\hline & Üst $\% 27$ & 5.00 & 5.00 & & & Üst $\% 27$ & 5.00 & .00 & \\
\hline
\end{tabular}


YYÜ Ĕ̆itim Fakültesi Dergisi (YYU Journal Of EducationFaculty),2017; 14(1):940-965,http://efdergi.yyu.edu.tr

http://dx.doi.org/10.23891/efdyyu.2017.35

ISSN:1305-020

\begin{tabular}{|c|c|c|c|c|c|c|c|c|c|}
\hline \multirow{2}{*}{ Madde 3} & Alt $\% 27$ & 2.69 & 1.21 & \multirow{2}{*}{-11.38} & \multirow{2}{*}{ Madde 18} & Alt $\% 27$ & 3.44 & .90 & \multirow{2}{*}{-10.27} \\
\hline & Üst $\% 27$ & 5.00 & .00 & & & Üst $\% 27$ & 5.00 & .00 & \\
\hline \multirow{2}{*}{ Madde 4} & Alt \%27 & 1.69 & .46 & \multirow{2}{*}{-25.72} & \multirow{2}{*}{ Madde 19} & Alt $\% 27$ & 1.75 & .55 & \multirow{2}{*}{-21.58} \\
\hline & Üst $\% 27$ & 4.61 & .49 & & & Üst $\% 27$ & 4.44 & .50 & \\
\hline \multirow{2}{*}{ Madde 5} & Alt \%27 & 2.27 & .70 & \multirow{2}{*}{-23.28} & \multirow{2}{*}{ Madde 20} & Alt \%27 & 1.63 & .48 & \multirow{2}{*}{-23.88} \\
\hline & Üst $\% 27$ & 5.00 & .00 & & & Üst $\% 27$ & 4.25 & .43 & \\
\hline \multirow{2}{*}{ Madde 6} & Alt $\% 27$ & 1.47 & .50 & \multirow{2}{*}{-25.35} & \multirow{2}{*}{ Madde 21} & Alt $\% 27$ & 1.58 & .50 & \multirow{2}{*}{-22.53} \\
\hline & Üst $\% 27$ & 4.50 & .50 & & & Üst $\% 27$ & 4.30 & .52 & \\
\hline \multirow{2}{*}{ Madde 7} & Alt \%27 & 1.80 & .46 & \multirow{2}{*}{-25.68} & \multirow{2}{*}{ Madde 22} & Alt $\% 27$ & 1.66 & .47 & \multirow{2}{*}{-23.66} \\
\hline & Üst $\% 27$ & 4.66 & .47 & & & Üst $\% 27$ & 4.33 & .47 & \\
\hline \multirow{2}{*}{ Madde 8} & Alt \%27 & 2.69 & .88 & \multirow{2}{*}{-15.56} & \multirow{2}{*}{ Madde 23} & Alt $\% 27$ & 1.72 & .45 & \multirow{2}{*}{-24.07} \\
\hline & Üst \%27 & 5.00 & .00 & & & Üst $\% 27$ & 4.44 & .50 & \\
\hline \multirow{2}{*}{ Madde 9} & Alt \%27 & 2.52 & .65 & \multirow{2}{*}{-20.89} & \multirow{2}{*}{ Madde 24} & Alt $\% 27$ & 1.75 & .43 & \multirow{2}{*}{-23.88} \\
\hline & Üst $\% 27$ & 4.94 & .23 & & & Üst $\% 27$ & 4.36 & .48 & \\
\hline \multirow{2}{*}{ Madde 10} & Alt \%27 & 2.38 & .83 & \multirow{2}{*}{-18.70} & \multirow{2}{*}{ Madde 25} & Alt $\% 27$ & 1.80 & .40 & 2465 \\
\hline & Üst $\% 27$ & 5.00 & .00 & & & Üst $\% 27$ & 4.25 & .43 & $-2+.0 J$ \\
\hline Modd 11 & Alt \%27 & 1.50 & .50 & 07 & Meds & Alt $\% 27$ & 2.66 & .82 & $0 ?$ \\
\hline iviauce is & Üst $\% 27$ & 4.58 & .50 & - & ivatue 20 & Üst $\% 27$ & 4.88 & .31 & -15.02 \\
\hline Moddo 12 & Alt \%27 & 1.63 & .48 & 30 & Modde 27 & Alt $\% 27$ & 1.72 & .45 & 801 \\
\hline 1vaduc Is & Üst $\% 27$ & 4.58 & .50 & . & 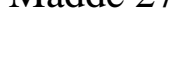 & Üst $\% 27$ & 4.72 & .45 & 20.01 \\
\hline Moddo 12 & Alt \%27 & 1.69 & .46 & 17 & 20 & Alt $\% 27$ & 1.30 & .46 & 0 \\
\hline 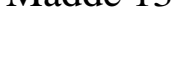 & Üst $\% 27$ & 4.63 & .48 & -20.17 & ivaude 20 & Üst $\% 27$ & 4.44 & .50 & -21.40 \\
\hline & Alt \%27 & 1.80 & .40 & & C 110 & Alt \%27 & 2.08 & .73 & מר 200 \\
\hline 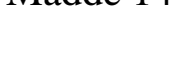 & Üst $\% 27$ & 4.52 & .50 & 20.21 & & Üst $\% 27$ & 4.97 & .16 & 20.0 \\
\hline & Alt \%27 & 1.75 & .55 & 7 & C 110 & Alt $\% 27$ & 1.00 & .00 & 0 \\
\hline iviauce is & Üst \%27 & 4.55 & .50 & -22.41 & iviaude so & Üst $\% 27$ & 4.16 & .84 & -22.40 \\
\hline
\end{tabular}

$* \mathrm{p}<.001$

Son olarak cinsiyet eşitliği ölçeğinin 3 alt analiz alanına ayrı ayrı güvenilirlik analizi yapılmıştır. Pallant'a (2001) göre, Cronbach alfa katsayısı. 7 ve üzeri çıkarsa ölçeğin güvenirliği yüksek kabul edilmektedir. Cinsiyet Eşitliği Ölçeği’nin iç tutarlığını belirlemek 

alan için. 77, eğitim öğretim alanı için. 86 ve kişisel alan için. 76 çıkmış olup, ölçeğin bütün alt kategoriler için güvenilir olduğu görülmektedir. Alt alanlar için ayrı ayrı güvenilirlik analizi yaptıktan sonra, bütün maddeler için tekrar analiz yapılmıştır. Bunun sonucunda, bütün maddelerin toplamında Cronbach alfa katsayısı. 78 çıtı̆̆ı için ölçek toplamda da güvenilir bulunmuştur.

Tablo 3. Güvenirlik Katsayıları

\begin{tabular}{ll}
\hline Kurumsal alt ölçeği & .77 \\
\hline Eğitim öğretim alt ölçeği & .86 \\
\hline Kişisel alt ölçeği & .76 \\
\hline Toplam ölçek & .78 \\
\hline
\end{tabular}

Ölçeğin Uygulanması: Ölçeğin geçerlilik ve güvenilirliği sağlandıktan sonra, ölçek Van ve Siirt illerinde öğretmenlik yapan 152 farklı öğretmene tekrar uygulamıştır. İkinci uygulamaya 97 kadın ve 55 erkek öğretmen katılmıştır. Ölçekte bulunan öğretmenlik deneyimi, okul tipi, yaş ve cinsiyet değişkenlerinden sadece cinsiyet literatür tarafından cinsiyet eşitliği ile ilgili kabul edilmektedir. Bu nedenle cinsiyet bağımsız değişken olarak kabul edilmiştir. Kadın ve erkek öğretmenlerin cinsiyet eşitliğine yönelik tutum puanlarının cinsiyete göre farklılık gösterip göstermediği MANOVA testi yapılarak araştırılmıştır. Ayrıca okul öncesi eğitim öğretmenlerinin cinsiyet eşitliğine yönelik açık uçlu sorulara verdikleri cevaplar incelenmiştir.

Tablo 4. Kurumsal, eğitim-öğretim, kişisel analiz puanlarının cinsiyete göre ortalama, standart sapma değerleri ve ANOVA sonuçları 
YYÜ Ĕ̆itim Fakültesi Dergisi (YYU Journal Of EducationFaculty),2017; 14(1):940-965,http://efdergi.yyu.edu.tr

http://dx.doi.org/10.23891/efdyyu.2017.35

\begin{tabular}{|c|c|c|c|c|c|c|c|}
\hline Değişken & Cinsiyet & $\mathrm{n}$ & $X$ & $\mathrm{~S}$ & $\mathrm{sd}$ & $\mathrm{F}$ & $\mathrm{p}$ \\
\hline \multirow[t]{2}{*}{ Kurumsal } & Kadın & 96 & 32.25 & 5.84 & $1-149$ & .35 & \\
\hline & Erkek & 55 & 33.83 & 5.78 & & & \\
\hline
\end{tabular}

\begin{tabular}{llllllll}
\hline $\begin{array}{l}\text { Eğitim- } \\
\text { Öğretim }\end{array}$ & Kadın & 96 & 28.03 & 5.86 & $1-149$ & .12 & .72 \\
\cline { 2 - 5 } & Erkek & 55 & 27.65 & 7.14 & & & \\
\hline Kişisel & Kadın & 96 & 41.67 & 7.50 & $1-149$ & .24 & .62 \\
\cline { 2 - 5 } & & & & & & & \\
& Erkek & 55 & 41.03 & 7.96 & & & \\
\end{tabular}

Cinsiyet Eşitliği Ölçeği kurumsal, eğitim-öğretim ve kişisel puanları üzerinde yapılan MANOVA sonuçları kadın ve erkek öğretmenlerin arasında anlamlı bir farklılık görülmediğini ortaya koymaktadır. Wilks Lambda $(\lambda)=0.99, F(2,148)=, 51 \mathrm{p}>.05 \mathrm{Bu}$ bulgu kurumsal, eğitim-öğretim, kişisel puanlarından oluşan doğrusal bileşenlerden elde edilecek puanların cinsiyete bağlı değişmediğini gösterir.

Ölçeğin üç alt boyutuna ilişkin ortalama ve standart sapma değerleri cinsiyete göre yapılan tek yönlü ANOVA sonuçları Tablo 4'te gösterilmiştir. Buna göre öğretmenlerin cinsiyet eşitliğine yönelik tutum puanlarında kurumsal alanda istatistiksel olarak anlamlı bir farklılık bulunmamıştır $\mathrm{F}(1,149)=0.35, p>.05$. Eğitim öğretim alt alanı için de istatiksel olarak anlamlı bir farklılık bulunmamıştır $\mathrm{F}(1,149)=0.12, p>.05$. Son olarak kişisel alt alanı için de istatiksel olarak anlamlı bir farklılık bulunmamıştır $\mathrm{F}(1,149)=0.24, p>.05 . \mathrm{Bu}$ sonuçlar okul öncesi eğitim öğretmenlerinin kurumsal, eğitim-öğretim ve kişisel alt alanlarında öğretmenlerin cinsiyetlerinden kaynaklanan bir fark olmadığını ve hem kadın hem de erkek öğretmenlerin sınıflarında cinsiyetçi kalıp yargılara ve önyargılara yer vermediklerini göstermektedir.

Açık Uçlu Sorular: Öğretmenlerin açık uçlu sorulara verdikleri yanıtlar içerik analizi yöntemi kullanılarak analiz edilmiştir. İçerik analizi genel olarak yazılı dokümanlara, deşifre 
http://dx.doi.org/10.23891/efdyyu.2017.35

edilmiş belgelere ya da kaydedilmiş sözlü iletişime odaklanır (Berg, 2007). Bir başka deyişle içerik analizi insan davranışlarını dolaylı yoldan inceleme fırsatı sağlayan bir yöntemdir. İnsanların iletişimine dair her türlü doküman onların bilinçli ve bilinç dışı inançları, tutumları, değerleri ve fikirleri hakkında bize bilgi verir (Fraenkel, Wallen \& Hyun. 2003). Çalışmaya katılan 152 öğretmenden 59’u açık uçlu sorulara cevap vermişlerdir. Açık uçlu sorulara cevap veren öğretmenlerin 42’si ilk soru olan cinsiyet ayrımcilığg yapmamaya örnek verirken sadece 17 tanesi ikinci soru olan cinsiyet ayrımcılığı yapılan durumlara örnek vermişlerdir. Açık uçlu sorulara verilen yanıtlar üzerinde yapılan içerik analizinde aynı içeriğe sahip yanıtların frekanslarına göre kategoriler oluşturulmuştur. Tablo 5 kategorileri ve frekanslarını göstermektedir. Ardından öğretmenlerin verdikleri yanıtlardan alıntılar yapılarak kategoriler örneklendirilmiştir.

Tablo 5. Öğretmenlerin Cinsiyet Eşitliğini Sağlamak Uygulamalarının Kategorileri ve Frekansları

\begin{tabular}{|c|c|c|}
\hline Kategori & Alt Kategoriler & Frekans \\
\hline \multirow[t]{2}{*}{$\begin{array}{l}\text { Oyun ve oyuncak seçiminde } \\
\text { cinsiyetten bağımsızlık }\end{array}$} & $\begin{array}{l}\text { K1z ve erkekler aynı oyuncaklarla oynayabilirler. } \\
\text { Buna teşvik edilirler. }\end{array}$ & 7 \\
\hline & $\begin{array}{l}\text { K1z ve erkekler serbest zamanda birlikte } \\
\text { oynamaya teşvik edilirler. }\end{array}$ & 2 \\
\hline \multirow[t]{3}{*}{$\begin{array}{l}\text { Cinsiyetçi olmayan sınıf } \\
\text { düzeni }\end{array}$} & $\begin{array}{l}\text { Gruplar oluşturulurken k1z ve erkekler eşit } \\
\text { dağıtılır. }\end{array}$ & 14 \\
\hline & Etkinliklerde bir kız bir erkek sıralanır. & 3 \\
\hline & Sınıftaki görevlerin eşit dağıtımı sağlanır. & 8 \\
\hline Cinsiyet eşitliği etkinlikleri & $\begin{array}{l}\text { Cinsiyet eşitliğini öğretmek için özel etkinlikler } \\
\text { planlanır. }\end{array}$ & 8 \\
\hline
\end{tabular}

Türkiye'nin doğusu daha ataerkil bir yapıya sahip olduğu için çocuklar okula belli cinsiyetçi kalıp yargılarla gelirler. Bu noktada, ailenin, toplumun ve medyanın çocukların 
cinsiyetçi tutumlar göstermesi konusunda ki etkisi yadsınamaz. Öğretmenler çocukların sahip oldukları bu kalıp yargıları yıkmak için öncelikle onların oyun ve oyuncakları arasındaki farkı ortadan kaldırmaya çalışmaktadır. Yine erkek öğretmenlerden biri çocukların kendi kendilerine oyuncakları cinsiyetlere göre ayırmaya nasıl meyilli oldukları şu şekilde ifade etmektedir: "Kızlar serbest zaman oyununda evcilik oynarken, erkekler daha çok araba ile oynamaktadır. Ben ise erkekleri evcilik oynama, kızları ise araba sürme oyununa teşvik ediyorum".

Sınıfta etkinlikler sırasında kızlar kız arkadaşlarıyla, erkekler ise erkek arkadaşlarıyla bir araya gelmeye istekli olduklarından, öğretmenlerin bu duruma müdahale etmesi gerekmektedir. Aşağıdaki alıntı bu durumu örneklendirmektedir: “...Sınıf içi etkinliklerde beraber hareket etme, sıra oluşturulurken bir kız bir erkek şeklinde sıralanmaları, hikaye zamanında minder ve sandalyelere aynı şekilde oturmalarını sağlamaya çalışıyorum”. (Ö42)

Ataerkil toplumlarda erkek çocuklara ev işlerinin yaptırılması çok sık rastlanan bir durum değildir. $\mathrm{Bu}$ durumun farkında olan öğretmen sınıfında erkek çocuklara da sınıfı temizleme görevi verdiğini ifade eder: "Sınıfi toplama veya temizleme zamanı erkek ögrenciye de ıslak mendil, gırgır vermek. Temizliği sadece bayanlar yapar algısından uzak tutma amacıyla yapılan bir uygulamadır”. (Ö60)

Erkek öğretmenlerden birisi ev işlerinin sadece kadınların görevi olmadığını erkelerin de bu işleri yapabileceklerini göstermek için çocuklarla bir etkinlik planlamıştır: "Çocuklara evde ütünüzü kim yapar diye sorduğumda 'Annemiz' diye cevap verdiler. Ben de erkeklerin de ütü yaptı̆̆ bir etkinlik yapmaya karar verdim. Hikaye yazdım”. (Ö14)

Öğretmenlerin okulda yaşadıkları cinsiyetçi ve ayrımcı durumlarla ilgili sadece bir kategori belirlenmiştir. Okullarda cinsiyetçi kalıp yargılar onlara karşılık gelen alt kategoriler ile birlikte Tablo 6'da verilmiştir.

Tablo 6. Öğretmenlerin Okulda Karşılaştıkları Cinsiyet Eşitsizliği Kategorileri ve Frekansları 


\begin{tabular}{lll}
\hline Kategori & Alt Kategoriler & Frekans \\
\hline Cinsiyet eşitsizliği & Çocuklardan kaynaklanan & 6 \\
\cline { 2 - 3 } & Ailelerden kaynaklanan & 5 \\
\cline { 2 - 3 } & Öğretmenlerden kaynaklanan & 4 \\
\cline { 2 - 3 } & Yönetimden kaynaklanan & 1 \\
\hline
\end{tabular}

Öğretmenlerin okulda karşılaştıkları cinsiyet eşitsizliği durumlarının çoğunluğunun çocukların kendilerinden kaynaklanması bu çalışmanın en düşündürücü bulgusudur. Çocukların kızlar uzun saçlı erkeler kısa saçlı olur, kızlar bebeklerle erkekler arabalarla oynar, erkekler ağlamaz, temizliği kızlar yapar gibi cinsiyetçi kalıp yargılara sahip oldukları görülmüştür. Okulda öğretmenlerin cinsiyetçi bir tutum izlemedikleri göz önüne alınınca çocukların cinsiyetçi tutumlarını aileden ya da toplumdan model alarak geliştirdikleri söylenebilir. Bu durumda okulun cinsiyetçi tutumlarla mücadelesinin önemi artmaktadır. Aşağıdaki örnekte çocukların cinsiyetçi tutumlarının sınıf içinde haksızlığa yol açtığı göz önüne alınırsa, bu davranışlar pekişmeden alınacak önlemler ilerde toplumsal cinsiyet eşitliğinin sağlamasına büyük katkı sağlayacaktır: "Serbest zamanda iki çocuk arasında kargaşa çıktı. Erkek çocuk kız çocuğundan arabayı alarak 'Kızlarda gidip bebeklerle oynasın' dedi’. (̈̈3)

Cinsiyetçi tutumlar iki cinsiyette de görülmektedir. Çocuklar okul öncesi eğitim ortamında bulunana kadar diğer cinsiyetle hiç oyun oynamamış olabilirler. Okul öncesi eğitim çocukların karşı cins ile sosyalleşebilmesi için de olanak sağlamaktadır. "Kız çocuk evcilik oynarken, erkek çocuk oyununa katılmak isteyince kız çocuk 'Erkekler kız oyunu oynamaz' dedi”. (Ö98)

Aşağıdaki alıntıda çocukların okul öncesi eğitimde davranış kazanma hızları cinsiyetçi yaklaşımların ortadan kaldırılmasında da gözlenmektedir: “ 'Sen kızsın bizimle oynama' diyor 
katılmasını istiyorlar”. (Ö54)

Ailelerden kaynaklanan cinsiyetçi tutumların hepsi erkek öğretmenlere yöneliktir. Çocukların eğitimi ile ilgilenen daha çok anneler olduğu için, erkek öğretmenler annelerle iletişim kurma ve güven sorunları yaşadıklarını belirtmişlerdir. Ailelerin bu olumsuz yaklaşımları çocuklarını okul öncesi eğitimden alıkoymaya kadar varmaktadır: "Erkek öğretmen olduğum için bir aile çocuğunu okula göndermek istemedi”. (Ö23)

$\mathrm{Bu}$ çalışmaya katılan öğretmenler cinsiyetçi kalıp yargıların farkında ve bunlarla mücadele etme eğiliminde oldukları için başka öğretmenlerin cinsiyetçi ya da ayrımcı uygulamalarına örnekler vermişlerdir: "Tanık olduğum bir olayda öğretmen arkadaşlarımızdan bir tanesi bez bebekle oynamak isteyen bir ögrencisini sertçe azarladı ve gidip arabalarla oynamasinı istedi”. (71)

Yönetimden kaynaklanan cinsiyet ayrımcılığı durumunun tek örneğini bir kadın öğretmen ifade etmiş̦tir: "Okulda bir görev yapılacak olsa hep kadın öğretmenlerin yapmalarını istiyorlar”. (Ö84)

\section{Tartışma}

Bu çalışmada Vendrell ve diğerlerinin (2014) geliştirdiği Cinsiyet Eşitliği Ölçeği (Gender Equity Scale) Türkçe’ye uyarlanmıştır. Ölçeğin uyarlama çalışmasına ilk olarak Türkçe'ye çevrilmesi ile başlanmıştır. Çeviri işlemi tamamlandıktan sonra yapı geçerliliğini test etmek için ölçek toplamda 46 erkek 92 kadın okul öncesi eğitim öğretmeninden oluşan örneklem grubuna uygulanmıştır. Yapı geçerliliğini sağlamak içim öncelikle madde analizleri yapılmıştır ve her maddenin kendi faktörü için düzeltilmiş madde-toplam korelasyon değerleri hesaplanmıştır. Madde analizinde düzeltilmiş madde-toplam korelasyon değerleri $\geq .30$ olarak kabul edilmektedir (Nunnally \& Bernstein, 1994). Korelasyon değerleri. 36 ile. 80 arasında 
http://dx.doi.org/10.23891/efdyyu.2017.35

ISSN:1305-020

olduğu için maddeler ayırt edici bulunmuştur. Bununla birlikte, madde analizi için ek olarak alt $\% 27$ ve üst $\% 27^{\prime}$ lik gruplarda yer alan katılımcıların puan ortalamaları bağımsız t-testi ile karşılaştırılmıştır. Bütün maddeler için $\mathrm{p}<.001$ düzeyinde anlamlı sonuç bulunduğundan ölçeğin madde ayırt edicilik gücünün yüksek olduğu sonucuna varılmıştır. Daha açık bir ifadeyle, ölçeğin yüksek puan alanlarla düşük puan alanları ayırt ettiği savunulabilir.

Ölçeğin güvenirliğini incelemek için Cronbach’s Alpha katsayıları hesaplanmıştır. Literatürde güvenirlik için kabul edilen değer >.7'dir (Pallant, 2001). Alt ölçeklerde Cronbach's Alpha katsayıları. 77, .86 ve. 76 bulunmuştur. Toplam ölçek için Cronbach’s Alpha katsayısı. 78 çıkmıştır. $\mathrm{Bu}$ katsayılara dayanarak ölçek güvenilir olarak değerlendirilebilir. Özetle, Cinsiyet Eşitliği Ölçeğinin Türkçe uyarlamasının okul öncesi eğitim kurumlarında cinsiyet eşitliğinin ölçülmesinde kullanılabileceği söylenebilir. Bu ölçüm okul öncesi eğitim kurumundaki resmi evraklar, eğitim öğretim faaliyetleri ve öğretmenlerin cinsiyet tutumlarına kadar cinsiyet eşitliği ile ilgili pek çok konuda bilgi sağlayacaktır.

Ölçeğin geçerlik ve güvenirliği sağlandıktan sonra 97'si kadın 55'i erkekten oluşan yeni bir örnekleme tekrar uygulanmıştır. Çalışmanın sonuçları okul öncesi eğitim öğretmenlerinin kurumsal, eğitim-öğretim ve kişisel alt alanlarında öğretmenlerin cinsiyetlerinden kaynaklanan bir fark olmadığını göstermiştir. Öğretmenlerin açık uçlu sorulara verdikleri cevaplar da hem kadın hem de erkek öğretmenlerin sınıflarında cinsiyetçi kalıp yargılara yer vermedikleri gibi toplumda var olan kalıp yargılarla mücadele ettiklerini göstermektedir.

Okul öncesi eğitim programına göre konu veya tema merkezli eğitim söz konusu değildir; ancak eğitim süreci planlanırken çeşitli konulardan yararlanılabilir. Burada asıl hedef çocuklara olumlu davranış kazandırmaktır. Kazandırılacak davranışlar okul öncesi eğitim programında yer alan kazanım ve göstergeler arasından seçilir (Milli Eğitim Bakanlığı, 2013). Programda cinsiyet eşitliği ile ilgili kazanım ve gösterge bulunmamaktadır. Fakat program 

kazandırmaya yönelik kazanım gösterge eklenebilir.

İlköğretim çağındaki çocuklarda cinsiyetçi kalıp yargılara sahip olanların genellikle düşük SES grubundan geldikleri gözlenmiştir (Kalaycı \& Hayırsever, 2014). Öğretmenlerin açık uçlu sorulara verdikleri cevaplardan anlaşıldığı üzere okulda cinsiyet ayrımcılığını en fazla çocuklar birbirlerine yapmaktadırlar. Bu çalışmaya katılan öğretmenlerin çoğunluğu da düşük SES’ye sahip ailelerin çocuklarına eğitim vermektedirler. Dezavantajlı çevreden gelen çocuklar için pek çok konuda bir müdahale programı gibi görülen okul öncesi eğitim cinsiyetçi kalıp yargıların önlenmesi için de bir müdahale olarak görülebilir (Blaise \& Taylor, 2012). Bu nedenle öğretmenlerin bu konudaki farkındalığın artırılması önem kazanmaktadır. Öğretmen yetiştirme programlarında toplumsal cinsiyet eşitliğine ilişkin derslerin yaygınlaştırılması, öğretmenlerin cinsiyet eşitliği konusunda daha iyi yetişmesine yardımcı olacaktır (Kalaycı \& Hayırsever, 2014).

Kadınlar tarafından daha fazla yapılan meslekler toplumda daha düşük prestije sahip olarak değerlendirilirler. Okul öncesi öğretmenliği de ağırlıklı olarak kadınlar tarafından icra edilen bir meslek olduğundan, toplumdaki statüsü çok yüksek değildir (Basten, 1997). Bu duruma bağlı olarak, aileler çocuklarını okula yazdırırken erkek öğretmenlerle karşılaştıklarında şaşırıp, olumsuz tepki gösterebilirler (Wennhoff, Nentwich \& Vogt, 2015). $\mathrm{Bu}$ çalışmada da erkek öğretmenler ailelerden olumsuz tepkiler aldıklarını belirtmişlerdir. Okul öncesi eğitim programına göre çocuk çevresinden ayrı düşünülemez, eğitim aktiviteleri çocuğun içinde bulunduğu kültürden bağımsız olarak planlanamaz. Ülkemizde halen dini ve kültürel nedenlerle erkek doktora muayene olmak istemeyen kadınlar olduğu bilinmektedir (Gürel \& Gürel, 2007). Küçük çocukların bakımları ve eğitimleri ile öncelikli olarak anneleri ilgilendiği için anneler erkek öğretmenlerle iletişime girmekten çekinip, onlara karşı olumsuz yaklaşıyor olabilirler. Bu durumu ortadan kaldırmak için aile katılımı etkinliklerinde babaların 
okula daha fazla gelmeleri ve çocuklarının eğitimine daha fazla katılmaları sağlanabilir (Pruett, Pruett, Cowan, \& Cowan, 2017). Bununla birlikte katı ataerkil toplumda erkek çocuklarının bebeklerle ya da evcilik köşesinde kız çocuklarıyla birlikte oynaması ailelerden olumsuz tepkiler alabilir. Öncelikle ailelere cinsiyet eşitliği hakkında bilgilendirme yapıp daha sonra sınıf içinde buna yönelik etkinlikler planlamak öğretmenlerin ailelerin desteğini almasına yardımcı olabilir.

Okula devam edemeyen 120 milyon çocuğun çoğunun kız olduğu göz önüne alındığında eğitimde cinsiyet eşitsizliği sadece ülkemizde değil küresel düzeyde bir sorun olarak karşımıza çıkmaktadır (Maya, 2013). Ülkemizde bu eşitsizlik önlenmeden, toplumsal ilerleme ve gelişmenin gerçekleştirilmesi mümkün görünmemektedir. Kalıp yargıların oluşmasında ve pekişmesinde etkili olan bir diğer faktör medyadır (Kalaycı, 2015). Medyanın verdiği cinsiyetçi mesajların yanında, ilköğretim kitapları da toplumsal cinsiyet eşitliğine ilişkin algıların, inançların ve düşüncelerin oluşması ve güçlenmesine yönelik hazırlanmamıştır (Esen \& Bağl1, 2002). Aksine toplumsal cinsiyet eşitsizliğini yaratan veya destekleyen açık ve örtük söylemler bulunmaktadır. Bu nedenle ders materyallerini ve etkinliklerini hazırlayanların, bilimsel bilgiden yararlanması ve muhtemel ön yargılarından arınması gerekmektedir. Öğrencilerin sahip olduğu geleneksel cinsiyetçi görüşlerinin farkına varmaları sağlanmalı ve cinsiyetçi yaklaşımlardan kurtulmalarını sağlayacak etkinlikler yapılmalıdır (Kalaycı \& Hayırsever, 2014). Okul öncesi eğitimde cinsiyet eşitliği üzerine daha fazla durulması ilerde toplumsal cinsiyet eşitliğinin sağlanmasında büyük rol oynayacaktır (Blaise \& Taylor, 2012). 


\section{Makalenin Bilimdeki Konumu}

Temel Eğitim/ Okul öncesi eğitim ABD

\section{Makalenin Bilimdeki Özgünlüğü}

Ülkemizde giderek tırmanan kadına karşı şiddet olayları, çocuk gelinler, kız çocuklarına ya da kadınlara uygulanan istismar durumlarının kökenini cinsiyet eşitsizliği ve cinsiyetçi kalıp yargılara dayandığ1 düşünülürse, okul öncesi eğitim bu istenmeyen tablonun önlenmesinde çok uygun bir ortam sunmaktadır. Okul öncesi eğitim programı çocuklara olumlu davranış kazandırmayı hedeflemektedir ve erken çocuklukta kazanılan davranışların uzun soluklu olduğu aşikârdır. Bu çalışma okul öncesi eğitim ortamlarında meydana gelebilecek cinsiyet eşitsizliği durumlarının belirlenmesi ve önlenmesine yardımcı olabilir.

\section{Kaynaklar}

Alan, İ. (2009). Sevgi içerikli çizgi filmlerin ilköğretim 5. sınıftaki çocukların görsel sanatlar dersinde yaptıkları resimler üzerindeki etkisinin incelenmesi. Yayımlanmamış yüksek lisans tezi, Gazi Üniversitesi, Ankara.

Aral, N., Ceylan, R. \& Bıçakçı M. Y. (2011). Çocukların televizyon seyretme alışkanlıklarının yaş ve cinsiyete göre incelenmesi. Kastamonu Eğitim Dergisi, 19(2), 489-498.

Asan, H. T. (2010). Ders kitaplarında cinsiyetçilik ve öğretmenlerin cinsiyetçilik algılarının saptanmas1. Fe Dergisi, 2(2), 65-74.

Ayrancı, Ü., Köşgeroğlu, N. \& Günay, Y. (2004). Televizyonda çocukların en çok seyrettikleri saatlerde gösterilen filmlerdeki şiddet düzeyi. Anadolu Psikiyatri Dergisi, 5,133-135.

Bandura, A.(1989). Human agency in social cognitive theory. American Sychologist American Psychological Association, 44(9), 1175-1179. 
Basten, C. (1997). A feminised profession: women in teaching profession. Educational Studies, 23(1), 55-62.

Berg, B. L., (2007). Qualitative research methods for the social sciences (6th ed.). Boston, MA: Allyn and Bacon.

Blaise, M., \& Taylor, A. (2012). Using queer theory to rethink gender equity in early childhood education. Young Children, 67(1), 88.

Esen, Y. \& Bağlı, M. T. (2002). İlköğretim ders kitaplarındaki kadın ve erkek resimlerine ilişkin bir inceleme. Ankara Üniversitesi Eğitim Bilimleri Fakültesi Dergisi, 35(1-2), 143-154.

Fraenkel, J. R., Wallen, N. E., \& Hyun, H. H. (1993). How to design and evaluate research in education (Vol. 7). New York: McGraw-Hill.

Günaydın, B. (2011). Çocuklara yönelik programlarda toplumsal cinsiyet rollerinin sunumu: TRT Çocuk ve Yumurcak TV. Uzmanlık Tezi, Radyo Televizyon Üst Kurumu, Ankara.

Gündüz-Kalan, Ö. (2010). Reklamda çocuğun toplumsal cinsiyet teorisi bağlamında konumlandırılışı: 'Kinder' reklam filmleri üzerine bir inceleme. İstanbul İletişim Fakültesi Dergisi, 38, 75-89.

Gürel, S. A., \& Gürel, H. (2007). Dölyolundan ultrason yapılan gebelerin incelemeyi yapan doktorun cinsiyeti ile ilgili tercihi ve gerekçeleri. Kadın Doğum Dergisi, 6(1), 1287 1291.

McCleary-Sills, J., Hanmer, L., Parsons, J., \& Klugman, J. (2015) Child marriage: A critical barrier to girls' schooling and gender equality in education. The Review of Faith \& International Affairs, 13(3), 69-80.

Kalaycı, N. (2015). Toplumsal Cinsiyet Eşitliği Açısından Bir Çizgi Film Çözümlemesi: PEPEE. Eğitim ve Bilim, 40(177), 243-270. 
Kalaycı, N., \& Hayırsever, F. (2014). Toplumsal cinsiyet eşitliği bağlamında Vatandaşlık ve Demokrasi Eğitimi ders kitabına yönelik bir inceleme ve bu konuya ilişkin öğrenci algılarını belirleme. Kuram ve Uygulamada Eğitim Bilimleri Dergisi, 14(3), 1065-1072. Maya, İ. (2013). Türk Eğitim Sistemindeki Cinsiyet Eşitsizliklerinin AB Ülkeleri ile Karş1laştırılması. Eğitim ve Bilim, 38(168).

Miles, M. B. \& Huberman, M. A. (1994). An expanded sourcebook qualitative data analysis. London: Sage.

Milli Eğitim Bakanlığı. (2013). Okul öncesi eğitim programı etkinlik kitabı. Erişim tarihi: 13 Mayıs 2015, http://tegm.meb.gov.tr/dosya/okuloncesi/okuloncesietkinlikkitabi.pdf adresinden alınmıştır.

Morrison, G. S. (2006). Fundamentals of early childhood education (4th ed). New Jersey: Pearson.

Nunnally, J. C. \& Bernstein, I.H. (1994). Psychometric theory (3rd ed.). New York: McGrawHill.

Oruç, C., Tecim, E. \& Özyürek, H. (2011).Okul öncesi dönem çocuğunun kişilik gelişiminde rol modellik ve çizgi filmler. EKEV Akademi Dergisi, 15(48), 281-297.

Pallant, J. (2013). SPSS survival manual (5th ed.). McGraw-Hill Education (UK).

Pruett, M. K., Pruett, K., Cowan, C. P., \& Cowan, P. A. (2017). Enhancing Father Involvement in Low-Income Families: A Couples Group Approach to Preventive Intervention. Child Development, 88(2), 398-407.

Sarıer, Y. (2010). Ortaöğretime giriş sınavları (OKS-SBS) ve PISA sonuçları 1şığında eğitimde fursat eşitliğinin değerlendirilmesi. Ahi Evran Üniversitesi Eğitim Fakültesi Dergisi, 11( 3), 107-129.

Tennhoff, W., Nentwich, J. C., \& Vogt, F. (2015). Doing gender and professionalism: Exploring the intersectionalities of gender and professionalization in early childhood education, European Early Childhood Education Research Journal, 23(3), 340-350. 

General on the Status Of Women. Ankara: Elma Technical Publishing.

Vendrell, R., Capdevila, R., Dalmau, M., Geis, A., \& Ciller, L. (2014). Descriptive study on gender Equity in early childhood education in Catalonia, Spaini. International Journal of Humanities and Social Scienc, 4(7), 279-290.

World Health Organization (WHO). (1998). The world health report. World Health Organization Publishing.

\section{Summary}

Problem Statement: Social gender roles are set of societal norms that represent men and women's roles and responsibilities. These roles are free from our biological gender and they are shaped by social, economic, and historical conditions. Our gender is biologically determined but gender roles are socially constructed. We have been learning social gender roles since babyhood. Choosing pink for girls and blue for boys creates unnatural discrimination for men and women (Üner, 2008). Biased gender roles that men are responsible for earning a living for family and women are responsible for house work and child rearing result in underrepresentation of women in labor to politics compared to men. Unfortunately, there are still discriminatory cultural values, differentiated according to the people's gender despite the increasing progressive women movements across the world. Although pre-school education is privileged environment to create awareness of gender equity, it has not been emphasized in teaching program until lately. Thus, it is essential to know how gender equality is takes place in an educational setting.

Purpose of the Study: Teachers' practices, belief and attitudes on gender equity are important as they are reflected to children and attitudes and behaviors gained in pre-school education have a long lasting impact on individuals. Therefore, this study scrutinizes teachers' practices on gender equity. In order to evaluate teachers' practices on gender equity a 

used to answer following questions:

1. What is attitude of pre-school education teachers' on gender equity?

2. Is pre-school education teachers' attitude scores towards gender equity differentiate based on their gender?

Method(s): This study was designed with the aim of adapting the Gender Equity Scale (Vendrell et al. 2014) into Turkish and it examined the scale's validity and reliability. It consists of three subscales, namely institutional, didactic and personal field. The institutional field focuses on the official documents of the school, administrators and staff working at school and looks into how gender equity values are represented in the documents, staff, pedagogical approach included in the questions of this subscales. The didactic field questions emphasize gender equity in programming, equitable assignment of chores in the classroom, and non-sexist language use. Finally, the field of personal beliefs is concerned with teachers' gender-based stereotypes in their teaching practices. The scale includes 30 items. In addition to 5-likert type questions, scale has two open ended questions. With the help of the four experts the scale was translated into Turkish. The Turkish version of the scale was administered to 46 male and 92 female pre-school education teachers.

Findings and Discussions: First of all validity analysis was conducted. If Cronbach's Alpha coefficient is higher than .70, a questionnaire is considered to be valid (Pallant, 2013). For the scale's internal consistency, Cronbach's Alpha coefficients were calculated for the Institutional subscale, didactic subscale, personal subscale and total scale and found to be .77 , $.86, .76, .78$ respectively. As a consequence, the properties of the Turkish version of the Gender Equity scale were satisfactory and could be used to assess gender equality in preschool education in Turkey. After adapting scale in Turkish, it is administered to 97 female and 55 male teachers again. A MANOVA test was conducted to compare the gender equity 

genders. Teachers' responds to open ended questions were analyzed utilizing content analysis and they confirm statistical result that both female and male teachers work and try to overcome gender stereotypes and prejudices.

Gender is accepted as independent variables among teaching experience, school types, and age since it is considered to have an effect on gender equity. A one-way between groups multivariate analysis of variance was performed to investigate sex differences in gender equity. Three dependent variables were used: Institutional, didactic, and personal gender equity scores. The independent variable was gender. There was not a statistically significant difference between males and females on the combined dependent variables Wilks Lambda $(\wedge)=0.99, F(2,148)=, 51 \mathrm{p}>.5$

Conclusions and Recommendations: These results showed that there is no difference among institutional, didactic and personal field score of teachers based on their gender. Both male and female teachers did not include gender stereotypes and biases in their class. In current patriarchal culture, children might come to school with gender stereotypes and these stereotypes can be challenges and/or transformed by teachers' interventions. As such, emphasizing gender equity more in pre-school education would play an important role to build a gender just society.

Keywords: Gender equity, pre-school education, scale adaptation 